DM どの他疾患合侀が 3 例でこれらには70Gy 前 後の照射が行われ，多くは約 1 年後に死亡した。ほか に治療拒否が 2 例，転医が 1 例. vii）手術した14例は $\mathrm{T} 1 ， 2 ， 3 ， 4$ それぞれ 2，9，1，2 例からなる. 頸 部操作だけで斉み皮弁で置換したもの3 例, 全抜去後 大弯側胃管挙上が 9 例, 結腸挙上が 2 例. 音声保存に ついては喉頭保存と同部切各 1 例. viii) 手術施行 214 例中健生は 6 例. ただし術後経過 2 年以内の 5 例を含 む. 死亡は初期の頃の手術合併症 2 例, 手術と照射に よる全身衰弱, 断端再発, Rouviere 転移, 肺転移, 他
疾患が各 1例ずつであった。質問 木西 賽(神戸 大). 頸部郭清術の郭清範囲，特に上方と，気管傍リン 八瀄郭清の範囲は. 質問 吉野邦俊(大阪成人病七 ンター)．1）胸骨柄切除による上縦隔郭清はどのよう な症例に対して行うか。2）気管壞死に宿らないような 郭清とは具体的にどのような方法か。応答 頚部 郭清術は一側根治的，他側内静脈保存で，ルビエル転 移に対する配慮は少ない，食道抜去の際に気管支動脈 などの板を損傷せ妨注意し，旁気管の郭清は若干 保護的に行う。

\title{
105.下咽頭癌におけるリンパ節転移の評価について
}

\author{
峯田周幸・水田邦博・森田浩史・酒井文夫・松永信治・野末道彦（浜松医大）
}

下咽頭癌は予後不良の疾患の 1 つであり, 当院の 5 生率好梨状陥山型 $41.2 \%$ ，輪状後部型 $55.0 \%$ ，後壁型 $38.1 \%$ あったた。死因の多くは頸部りンパ節の再 発及び遠隔転移であった。そこで，今回私たちは術前 に施行した各種のリンパ節評価（触診・Ga シンチ・ CT・エコー）を，病理所見と比較検討した，対象は， 咽院頭全摘または咽喉頭食道全摘を行い，かつ患側の 根治的頸部郭清術・健側の保存的頸部郭清術を行った 20例である。術後の病理所見で転移が確認されたもの は15例で，うち5例は対側にも認められた。転移の部 位は，同側で上深頸領域13例・中深頸領域 6 例・下深 頸領域 2 例・鎖骨上窝 1 例・副神経領域 1 例であった。 対側では，上深頸領域 3 例・中深䯪領域 2 例であった。 各領域の転移を合わせた件数でみると，触診で転移を 疑わせた22件について，うち20件でリンパ節転移が確 認され，2件は false positiveであった。一方, false negativeは 9 件であった，Gaシンチで転移を疑わせ た11件中10件に転移於確諗され，false positiveは1件 であった. false negative は15件であった.CTでは16 件中12件に軾移が確認され，false positive は 4 件であ った. false negative は12件であった.エコーでは22件 中15件に転移が確認され，false positiveは 7 件であっ た. false negativeは 4 件であった. 各種検査の結果を
みると, false positiveの少ないものが, Ga シンチ, 触診であり，一方 false negativeの少ないものが，工 コーであった。

各種検查を組み合わせることによるリンパ節評洒の 変化をみると, 触診だけでは過小評価 5 例, 過大評価 2 例であったが, 触診と CT では過小評值が 3 例にな つた。また，触診にエコーを組み合わせると，過大評 洒 4 例，過小評価 0 例であり，これはCT を追加して 変化注なかった。

下咽頭癌の予後が不良なこと, また頸部りンパ節の 再発が多いことなどを考えると, 術前のリンパ節評価 をする際に，過小評価をなくす必要があり，そのため には，頸部エコ一検榃が有用と考えられだ。質問 宮原 裕(奈良医大)。エコー, CT で陽性例の術後陽性 の最小リンパ節は (size)。応答 $\phi 1 \mathrm{~cm}$ 程度が最 小のものであった。質問 古川政樹(横浜船員保 険)．1）エコーで偽陽性例が多いとのことだがエコー による転移陽性の診断基準は。2) 画像診断による浐断 能を検討する場合，存在猃断々質的診断を分けて考え るべきと思うが如何．応答 1) エコーにて同定さ れたもの，とくに樑頸部領域のものは陽性と判断した。

2) 質的䛦断として, 術前に aspiration biopsy 等は行 つていない.

\section{6. 下咽頭と食道の重複癌症例の外科的治療}

\author{
中溝宗永・鎌田信悦・川端一嘉・高橋久昭・苦瓜知彦・島田士郎 \\ 保喜克文・河西信勝・内田正興（癌研附属病院）
}

頭頸部，上部消化管は multicentric な発癌が見られ ることはよく知られている，2つの癌の治潦で術野や 照射野が相重なることは興味ある問題であるが，その 治療に関して述べられた報告は少ないので，重複癌症 例の中から下咽頭と食道の重複癌症例の手術治療実施 例の経験を再建に主眼をおいて報告した。
対象 過去15年間に当科で治療した下咽頭癌218例 のうち食道癌の重複を認めた症例は20例である。この うち下咽頭と食道の双方の癌に外科的治療が実施され た症例は11例あったが，1例は他院ての食道癌手術の 詳細が不明であるため除外し，10例を今回の検討の対 象とした。なお下咽頭癌は術前照射あるいは根治照射 
が実施された上で手術となった。

䊅果 双方の癌が一度の手術で切除された症例はな 加った。両手術の間隔は 1 年以内が 3 例で残り7例は 1 年以上の間隔があった。手術の順序は食道癌手術先 行が 3 例, 下咽頭癌手術先行が 7 例であった。手術間隔 が 1 年以内であった 3 例のうち 2 例が食道癌手術先行 例（他院治療例と古い当院治療例）であった．下咽頭 癌手術が頸部郭清術のみで終わっている症例が 1 例あ つた，食道再建には胃管が 5 例，有茎結腸が胃切の既 往ある2例に用いられ, 胸腔内胃食吻合が 2 例, 前胸 皮周管利用が1例あった。 下咽頭再建にはDP皮弁が 3 例，前腕皮弁が 2 例，遊離空腸が 4 例に用いられた。 いずれの症例も重篤な合併症を経験していないもの の，胸部食道再建が胸壁前ルートであった 2 例で両再 建臓器間の縫合不全が生じた。食道癌手術先行と下咽 頭癌手術先行の各々 1 例であり, 共に前腕皮弁一有茎
結腸使用例で保存的に治癒した minor leakage であ つた，後行手術の食道再建の際に頸部で吻合操作が必 要となった症例は 7 例あった。二度にわたる気管孔周 囲の処理に際して慎重な気管膜様部の剝離が必要とさ れ，先行手術で遊離空腸を使用した最近の症例では当 然ながら腸管の栄養血管の保護も要求された。死因は 食道癌死が 7 例, 判定不能が 1 例であった。残り 2 例 は長期生存を得ている。10例の下咽頭癌としての生存 率は 2 年生存が $50 \%, 5$ 年生存は $40 \%$ であった。質 問 武宮三三(千葉がんセンター).1) 臘壁前挙上例で 縫合不全が起きやすい理由、2)胸壁前挙上の適応につ いて。応答 1) minor leakage 発生の明確な理由 は不明である.2）胸壁前ルートの方が結腸吻合に tensionがかからないのと結腸の压迫による血流不全が 少ないと考えられたからである(外科サイドの評価).

\section{7. 喉頭癌の治療成績とそれを向上させる一要因について}

\section{臼居洋行・竹生田勝次・西嶌 渡・広田敦子（埼玉県立がんセンター）}

目的睺頭癌は放射線治療及び手術治療により，他

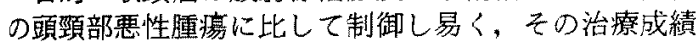
は上限に近づきつつあるように思われる。しかし，臨 末からは，まだまだ治療成績を向上できる要因が含ま れているような印象を受ける。というのは，喉頭癌が 制御されたにもかかわらず，第二の癌あるいは他の疾 患により不幸な転帰をとる症例に時々遭遇するからて ある。そこで当センタ一開設以来経験した喉頭癌の一 次治療症例に扔いて，その治療成績を明らかにすると 同時に，喉頭癌以外の他因子が予後にどの程度関与す る加について検討を加えた。

対象 1975年11月より1989年11月までに当科にて一 次治療を行った喉頭癌症例は260例であった。部位別で は，声門上癌90例 (34\%)，声門癌159例 (61\%)，声門 下癌11例（4\%）であった。病期別では，病期 0 は 1
例，I は119例(46\%)，II は53例(20\%)，IIIは56例(22 \%)，IVは31例 $(12 \%)$ であった。男女比は9:1で，年

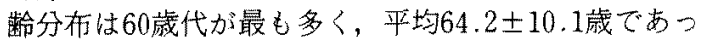
た。他因死は47例で，重複癌によるものが最も多く21 例 (45\%)であった。

まとめ 全体の 5 年生存率は $71 \%$ であった。部位別 では声門癌は $81 \%$, 声門上癌は $54 \%$, 声門下癌は $80 \%$ であった。声門癌と声門下癌との間には有意差（ $\mathrm{p}<$ 0.001)方認めら扎た。病期別では I IIIは $59 \%$, IVは 40\%で，II とIIIでは有意差（p<0.1） が認められた。他因死を除いた生存率は $86 \%$ であった。 他因死は重複癌が $44 \%$ 占めており, 今後の課題とし て, 他因死特に重複癌の制御が喉頭癌の生存率の向上 の一要因と考えられた。

\section{8．喉頭癌における重複癌症例の検討}

\section{谷川譲・中村 弦・海老原秀和・仲 博美・宮下久夫（都立駒込）}

目的頭頸部癌の中では喉頭癌が最も多いが, 比較 的早期発見率が高いので予後は一般に良い。しかし高 齢化と共に重複癌の発見も增加の傾向にある。喉頭癌 と治療成績向上のためには是非重複癌の早期発見と治 療が必要である。そのために注日頃の診療でいかなる 注意が必要かを検討した。

方法 都立駒込病院で昭和51年から63年迄の12年間 に治療した喉頭癌症例は151例で, 重複癌は21例(約14 \%)認めた。この症例につけて，二次癌の発生部位上
数, 発生時期(同時, 異時), 発見の方法, 発見上り死 亡汽の期間, 死亡原因, 二次癌の治療法, Brinkman 指 数等，何か特徵㹥ない加を検討した。特に二次癌の早 期発見には診察期間，検查項目等何が大切か子皆問題と Lた。

結果 1. 二次癌は肺が一番多く, 以下䏴, 甲状腺, 食道, 肝, 中咽頭, 下咽頭の順であった。三重癌が 4 例あった. 2. 原発治療から死亡迄の期間は, 原病死の 場合短〉, 1 年以内如死亡し, 同時重複癌では, 根 